http://kitaibelia.unideb.hu/

ISSN 2064-4507 (Online) • ISSN 1219-9672 (Print)

(C) Department of Botany, University of Debrecen, Hungary

27(1): 16-26.; 2022

DOI: $10.17542 /$ kit.27.007

research paper • eredeti közlemény

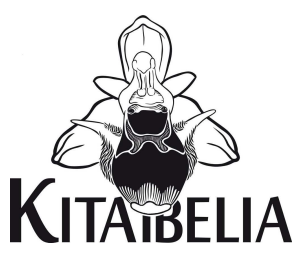

\title{
Új montán fajok a magyar mohaflórában
}

\author{
NÉMETH Csaba ${ }^{1 *} \&$ SCHMOTZER András ${ }^{2}$ \\ (1) ELKH Ökológiai Kutatóközpont, Ökológiai és Botanikai Intézet, H-2163, Vácrátót, Alkotmány u. 2-4.; \\ nemetcsaba@gmail.com \\ (2) Bükki Nemzeti Park Igazgatóság, H-3304, Eger, Sánc u. 6.
}

\section{New montane species in the Hungarian bryophyte flora}

\begin{abstract}
During a bryofloristical investigation in the vicinity of Ómassa (Miskolc) in the Bükk Mountains (NE Hungary), three montane-boreal bryophyte species new to the Hungarian bryoflora were collected. Encalypta spathulata Müll.Hal. was found on the ledges of limestone cliffs of Vörös-kő Hill as well as on the rocky debris among roots of a fallen tree lying under the cliffs. Hydrogonium croceum (Brid.) Jan Kučera and Orthothecium rufescens (Dicks. ex Brid.) Schimp. were found in the crevices of dolomite cliffs on the north-facing steep slope of Jávor Hill. While the latter two species are widespread in European Mountains, E. spathulata is considered to be a rare species, and is assessed as 'Vulnerable' in the IUCN red list.
\end{abstract}

Key words: alpine-boreal mosses, Bükk Mountains, Hungary, red-listed species

Összefoglalás - A szerzők a Központi-Bükk mohaflorisztikai kutatása során három, Magyarország területéről eddig nem ismert mohafaj előfordulását mutatták ki az ómassai Vörös-kő (Encalypta spathulata Müll.Hal.) és a Jávor-hegy (Hydrogonium croceum (Brid.) Jan Kučera, Orthothecium rufescens (Dicks. ex Brid.) Schimp.) mészkő-, illetve dolomit szikláiról. Mindhárom faj montán, alpin-boreális flóraelem, és jelenlétük a Bükk ezen részének erőteljes montán karakterét hangsúlyozza. Míg a H. croceum és az 0 . rufescens Európa hegyvidéki területein gyakori és elterjedt faj, addig az E. spathulata IUCN vörös listás növény (VU, sebezhető besorolással), így a Bükkben felfedezett populációja kontinensléptékben is jelentőséggel bír.

Kulcsszavak: alpin-boreális mohafajok, Bükk hegység, vörös listás fajok

\section{Bevezetés}

Változatos geológiai és geomorfológiai adottságainak köszönhetően a Bükk hegység hazánk egyik legváltozatosabb edényes flórájú területe (VojTKó 2001). Míg a hegység nyugati peremén magasodó Bélkőn melegkedvelő preglaciális reliktum fajokat (Calamintha thymifolia (Scop.) Rchb., Ferula sadleriana Lebed.) találunk, a hegység szűk, meredek oldalú szurdokvölgyei, azok északias kitettségú lejtői, mészkő-, dolomit- és bazaltsziklái montán fajok, esetenként alhavasi reliktumok előfordulását teszik lehetővé (pl. Allium victorialis L., Arabis alpina L., Clematis alpina (L.) Mill., Saxifraga adscendens L., Valeriana tripteris L., Viola biflora L. stb.).

Ez a széles ökológiai spektrumot felölelő fajgazdagság a Bükk mohaflórájára is jellemző (Boros 1968). A délies kitettségű sziklák, sziklagyepek melegkedvelő fajai (pl. Buckia vaucheri (Lesq.) D. Rios, M. T. Gallego et J. Guerra, Fabronia pusilla Raddi, Frullania cleistostoma Schiffn. et W. Wollny, Grimmia anodon Bruch et Schimp., Grimmia teretinervis Limpr., Mannia 
fragrans (Balb.) Frye et L. Clark, Schistidium brunnescens Limpr.) mellett az északias kitettségű sziklaerdők, sziklagyepek, sziklafalak számos montán, alpin-boreális flóraelemnek kínálnak kedvező létfeltételeket (pl. Marchantia quadrata Scop., Metzgeria pubescens (Schrank) Raddi, Orthothecium intricatum (Hartm.) Schimp., Plagiopus oederianus (Sw.) H. A. Crum et L. E. Anderson, Ptychostomum zieri (Hedw.) Holyoak et N. Pedersen, Scapania aequiloba (Schwägr.) Dumort., Timmia bavarica Hessl.) (BoROs 1968, ORBÁN 1980).

A Bükk mohaflórája hazai viszonylatban jól kutatott, Boros Ádám és Vajda László számos gyűjtőutat tett a hegységbe (BoRos 1915-1971). A terület mohaflórájának Boros által felvázolt képét (BOROS 1968) később további fajok kimutatásával számos kutató színesítette (SILLER 1979, ORBÁN 1980, Tóth 1987, PÉNZESNÉ KóNYA \& ORBÁN 2000, PAPP \& ERZBERGER 2003, ERZBERGER \& SCHRÖDER 2008, ORBÁN et al. 2009, ERZBERGER 2009, 2014, ERZBERGER et al. 2015, SZǓCS et al. 2015, CASPARI \& ERZBERGER 2019). A hegység mohaflorisztikai jelentőségét emeli az a tény is, hogy hazai viszonylatban a Bükk kiemelten gazdag európai Vörös Listás mohafajokban (PAPP 2008).

Ilyen kutatási előzmények után - talán kissé meglepő módon - az Ómassa környéki területek mohaflorisztikai vizsgálata során három, mind a Bükk hegységre nézve, mind pedig a hazai mohaflórára új faj került elő (NÉMETH \& SCHMOTZER 2021a, b). Mindhárom faj (Encalypta spathulata Müll.Hal., Hydrogonium croceum (Brid.) Jan Kučera, Orthothecium rufescens (Dicks. ex Brid.) Schimp.) előfordulása a Központi-Bükk már régóta közismert, erőteljes montán jellegét hangsúlyozza.

\section{Anyag és módszer}

A terepi felmérések elsősorban a közösségi jelentőségű mohafajok (Buxbaumia viridis (Lam. \& DC.) Moug. \& Nestl., Mannia triandra (Scop.) Grolle) ismert és potenciális élőhelyeinek feltárására koncentráltak, mely feladat mellett általános mohaflorisztikai felmérések is zajlottak 2021. január és július között. A terepi adatgyűjtés során adatrögzítésre Spectra Mobilemapper GPS vevőkészüléket használtunk. A lelőhelyeknél a flóratérképezési negyedkvadrát azonosító kódja is feltüntetésre került (lásd KIRÁLY 2003). A tanulmányban közölt lelőhelyek (dúlőnevek) értelmezését az 1. ábra segíti. A bizonyító herbáriumi példányok az első szerző, valamint az MTM Növénytár (BP) herbáriumába kerültek, továbbá a fajok előfordulásáról fényképfelvételeket is készítettünk. Az edényes fajok nevezéktana KIRÁLY (2009), a moháké ERZBERGER \& PAPP (2020) munkáját követi. A társulástani egységek megnevezése BoRHIDI (2003), a geológiai formációké pedig PELIKÁN (2005) munkája alapján történt.

A vizsgált terület a Garadna-völgy felső részét foglalta magába. A bükki léptékben is igen tagolt, sziklaformákban gazdag - kelet-nyugati futásirányú - völgy a Nagy- és a Kis-fennsíkot vágja ketté. A völgyfő nagyjából Ómassánál található (ahol maga a Garadna-forrás is ered), ahová több, a fennsíkról lefutó völgy is kapcsolódik (pl. a Vöröskőt tagoló Farkasnyaki- és Száraz-völgy). A terület földtani és tektonikai tekintetben igen változatos, a domináns triászkorú mészkövek mellett - kiemelten a Jávor-hegy északi lejtőjén - megjelenik a középső triász (anizuszi), szürke, kalciteres dolomit is. A rétegsor részben rétegzetlen, de pados megjelenés is előfordul (SZABó 1981). Az általunk vizsgált, a Bükk-fennsík térszínénél jóval alacsonyabb, 550-600 méter tengerszint feletti magasságú terület montán élőhelyeinek kialakulása több tényezőre vezethető vissza. A geomorfológiai adottságoknak megfelelően a meredek, erősen szűkülő fő- és oldalvölgyek oldalában igen sekély rendzinatalaj alakult ki, ahol a talajfejlődést - kiemelten a dolomit alapkőzetű oldalakon - a folyamatos erózió hátráltatja. A mikroklíma (bár konkrét mérési adatsorokkal nem rendelkezünk) az északi kitettségú oldalakon jóval hűvösebb, mint a tengerszint feletti magasságból adódó makro-, illetve mezoklíma. A Bükk hegységben az évi középhőmérséklet az országos átlagnál körülbelül $2{ }^{\circ} \mathrm{C}$ kal alacsonyabb, mindössze $7-8^{\circ} \mathrm{C}$, a Bükk-fennsík legmagasabb részein pedig még ennél is 
alacsonyabb, csupán $6^{\circ} \mathrm{C}$. A Jávor-hegy alatt fakadó, állandó jellegű Garadna-forrás a völgyet egész évben párásabbá, hűvösebbé teszi a környező - felszíni vizekben szegény - térszínekkel összevetve. A Bükk csapadékviszonyai is sajátos mintázatot mutatnak. Az 1961-1990 évi adatsorok alapján megállapítást nyert (KovÁcs 2017), hogy a Bükk-fennsíktól 200-300 méterrel alacsonyabban fekvő Ómassa csapadékmérő állomása is számottevően magasabb csapadékátlagot mutat, mint a környező, lényegesen magasabb hegytetőkön kihelyezett mérőállomások (Jávorkút, Szentlélek). Ezen természeti adottságok egyértelműen meghatározzák a növénytársulások kialakulásának feltételeit, mely az extrazonális (sziklai) növénytársulások magas részesedésében is megmutatkozik. Speciális adottságai alapján VojTKó (2001) önálló növényföldrajzi egységként határolta le a Garadna-völgyet az Északi-Bükk egységen belül.

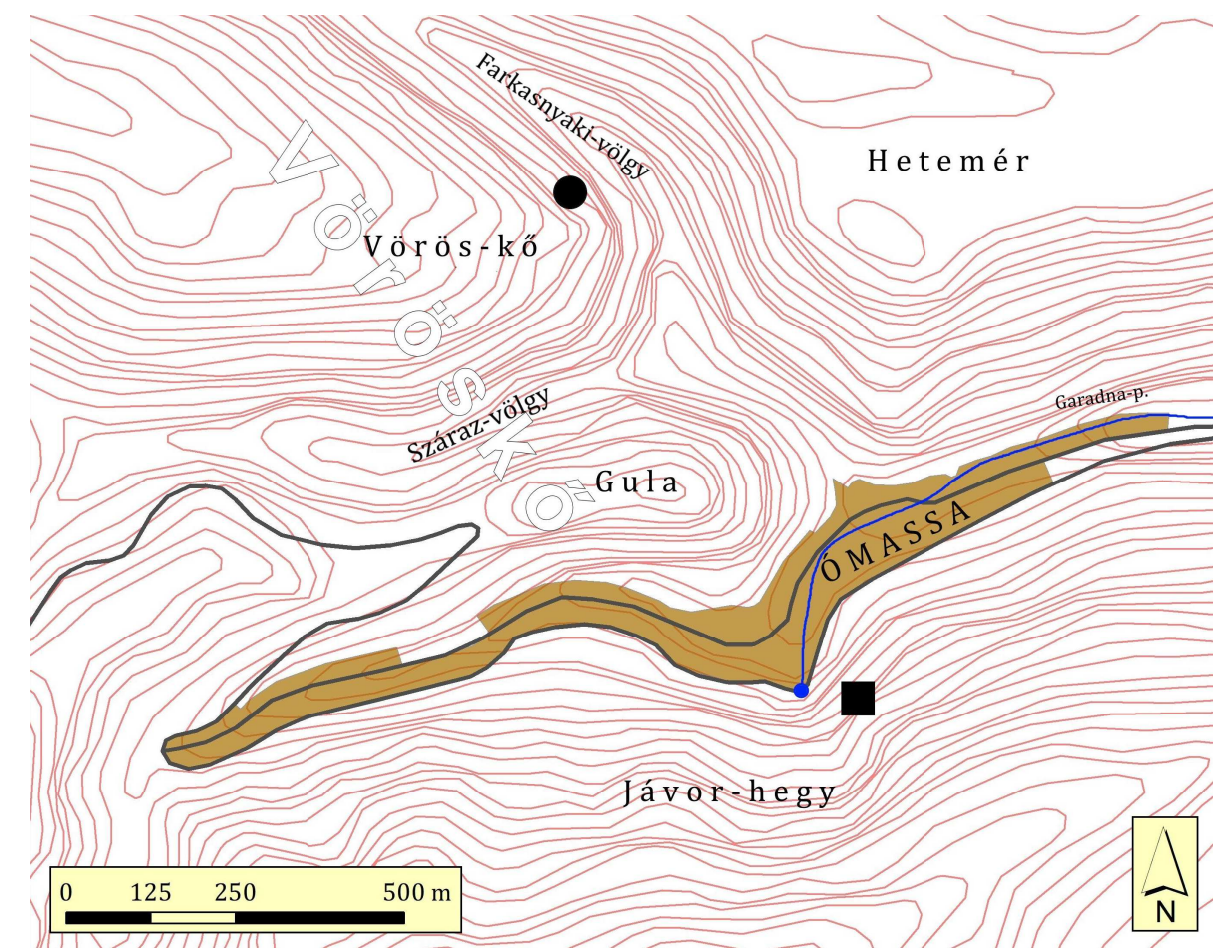

1. ábra A Hydrogonium croceum és az Orthothecium rufescens ( $\mathbf{\square})$, valamint az Encalypta spathulata (৩) előfordulása a Bükk hegységben Fig. 1 Localities of Hydrogonium croceum and Orthothecium rufescens ( $\mathbf{\square})$ as well as Encalypta spathulata (-) in the Bükk Mountains

\section{Eredmények}

Hydrogonium croceum (Brid.) Jan Kučera (syn.: Barbula crocea (Brid.) F. Weber \& D. Mohr)

Európai és Észak-Afrikai elterjedésű, magashegyi karakterrel rendelkező faj, elterjedésének súlypontja a Mediterráneum és Közép-Európa térsége (NEBEL \& PHILIPPI 2000). A Magyarországot határoló országok mindegyikében előfordul (HODGETTS \& LOCKHART 2020). Hazánkban a bükki Ómassa felett magasodó Jávor-hegy északi kitettségű, függőleges dolomitszikláinak repedéseiből került elő (KEF: 7889.3; N 4806'28.3", E 20³1'56.7", 570 m, 2021. 03. 26., 2021. 07. 06. leg. Németh Cs. és Schmotzer A., det. Németh Cs., conf. P. Erzberger (hb. Cs. Németh 10490, 10692, BP 196618) (1, 2a ábra). 
Olívzöld, zöld vagy sárgás-barnás színű, sűrű gyepekben növő faj (2b ábra). Lándzsás vagy tojásdad-lándzsás levelei (3a ábra) szárazon kissé csavarodottak, nedvesen elállók, a levélszél sima vagy a levél alsó felében kissé begöngyölt, hullámos, felül szabálytalanul fogazott. A levélcsúcs tompa, a levélér erőteljes, a csúcsban kis szálkahegy formájában kilépő, kezdetben zöld, idősebb leveleken vörösesbarna ( $3 \mathrm{~b}$ ábra). A levélsejtek sűrűn papillásak, többnyire átlátszatlanok, lekerekített négyzetesek, 5-11 × 5-9 $\mu \mathrm{m}$-esek, a levélalapi sejtek téglalap alakúak, 40-50 × 7-11 $\mu \mathrm{m}$-esek, simák, átlátszók, sárgák. Nagyméretű (200-500 $\mu \mathrm{m}$ hosszú), kb. 100 sejtből álló, nyeles, ellipszoid vagy tojásdad alakú, barnásvörös levélhónalji gemmái mindkét végükön kihegyezettek (2c, 3c ábra) (NyHolm 1998, AHRENS in Nebel \& PHILIPPI 2000, GARILLETI in GUERRA et al. 2006). Kétlaki faj, bükki élőhelyén sporofitonos egyedeket nem észleltünk.

Sajátos megjelenésű gemmái, valamint a levélcsúcs alatti levélszél szabálytalan fogazottsága alapján könnyen azonosítható faj. Hasonló, közelrokon faj a Hydrogonium consanguineum (Thwaites et Mitt.) Hilp., mely szintén levélhónalji gemmákat fejleszt, de azok kisebb méretűek (35-55 × 60-130(-210) $\mu \mathrm{m}$, KöCKINGER et al. 2012), sötétvörösek, buzogány alakúak, és jóval kevesebb (kb. 10) sejtből állnak. Széles elterjedésű, főleg a trópusi és melegmérsékelt övi területeken előforduló faj (ZANDER 1994), mindössze egyetlen régi, Boros Ádám által 1925-ben gyüjtött magyarországi adattal (GALAMBOS 1992, KöCKINGER et al. 2012). A H. consanguineum hazánkban vélhetően csak ideiglenesen megtelepedett faj.

Hasonló taxonok még a Magyarországon elég ritka Streblotrichum convolutum (Hedw.) P. Beauv. var. commutatum (Jur.) J. J. Amann (syn.: Barbula convoluta var. sardoa Schimp) és a széles körben elterjedt Barbula unguiculata Hedw., de ezek egyike sem képez levélhónalji gemmákat és leveleiken a levélcsúcs alatti fogazás is hiányzik.

\section{Orthothecium rufescens (Dicks. ex Brid.) Schimp.}

Európa magasabb hegyvidékein, boreális területein előforduló faj. Jellemzően árnyas mészkő- vagy dolomitsziklák repedéseiben, visszahajló sziklafalakon él (BIRKS \& HODGETTS 2014). Valamennyi Magyarországgal határos országban megtalálható (HODGETTS \& LOCKHART 2020). A Bükkhöz legközelebbi dokumentált előfordulása a Murányi-fennsíkról és a Szepes-Gömörikarsztról („Szlovák Paradicsom”) ismert, előbbi helyen a fentebb tárgyalt H. croceum-mal együtt fordul elő (HERBEN et al. 1982, HERBEN \& SOLDÁN 1987). A faj a Nyugati-Kárpátok alhavasi övében, 1300-1700 méteres magasságban, meredek dolomit- és mészkőletöréseken megjelenő magcsákós-merev sásos (Dryado octopetalae-Caricetum firmae) gyeptársulás egyik szubasszociációjának (primuletosum auriculae) differencális fajának számít (Šıí́K et al. 2004). Hazánkban a bükki Jávor-hegy északi kitettségű, függőleges dolomitszikláinak repedéseiből került elő (KEF: 7889.3; N 4806'28.3", E 20³1'56.7", 570 m, 2021. 03. 26., 2021. 07. 06. leg. Németh Cs. és Schmotzer A., det. Németh Cs., conf. P. Erzberger (hb. Cs. Németh 10489, 10689, BP 196617) (1, 2d ábra).

Sürü, fénylő, gyepekben növő, zöldesvörös vagy vörös színű növény (2e ábra). Levelei 2-4 mm hosszúak, elállók, keskeny háromszög-lándzsásak, a levélalapból fokozatosan hosszú, hegyes csúcsba keskenyedők, erőteljesen hosszredősek, általában ér nélküliek (2f ábra), a levélszél visszahajló. A levélsejtek hullámosak, a levél közepénél keskenyek, hosszúkásak, szélességüknél 12-20-szor hosszabbak (SMITH 2004, BIRKS \& HoDGETTS 2014). Kétlaki, spóratokot csak ritkán fejleszt, bükki élőhelyén sem észleltünk sporofitont.

Hasonló élőhelyeken előforduló, Magyarországon szintén ritka faj az Orthothecium intricatum, de ez utóbbi kisebb termetű, alig vagy kevésbé vöröslő levelei jellemzően egy irányba görbülők, legfeljebb $2 \mathrm{~mm}$ hosszúak, nem hosszredősek, sima levélszéllel. 
Kitaibelia 27(1): 16-26.

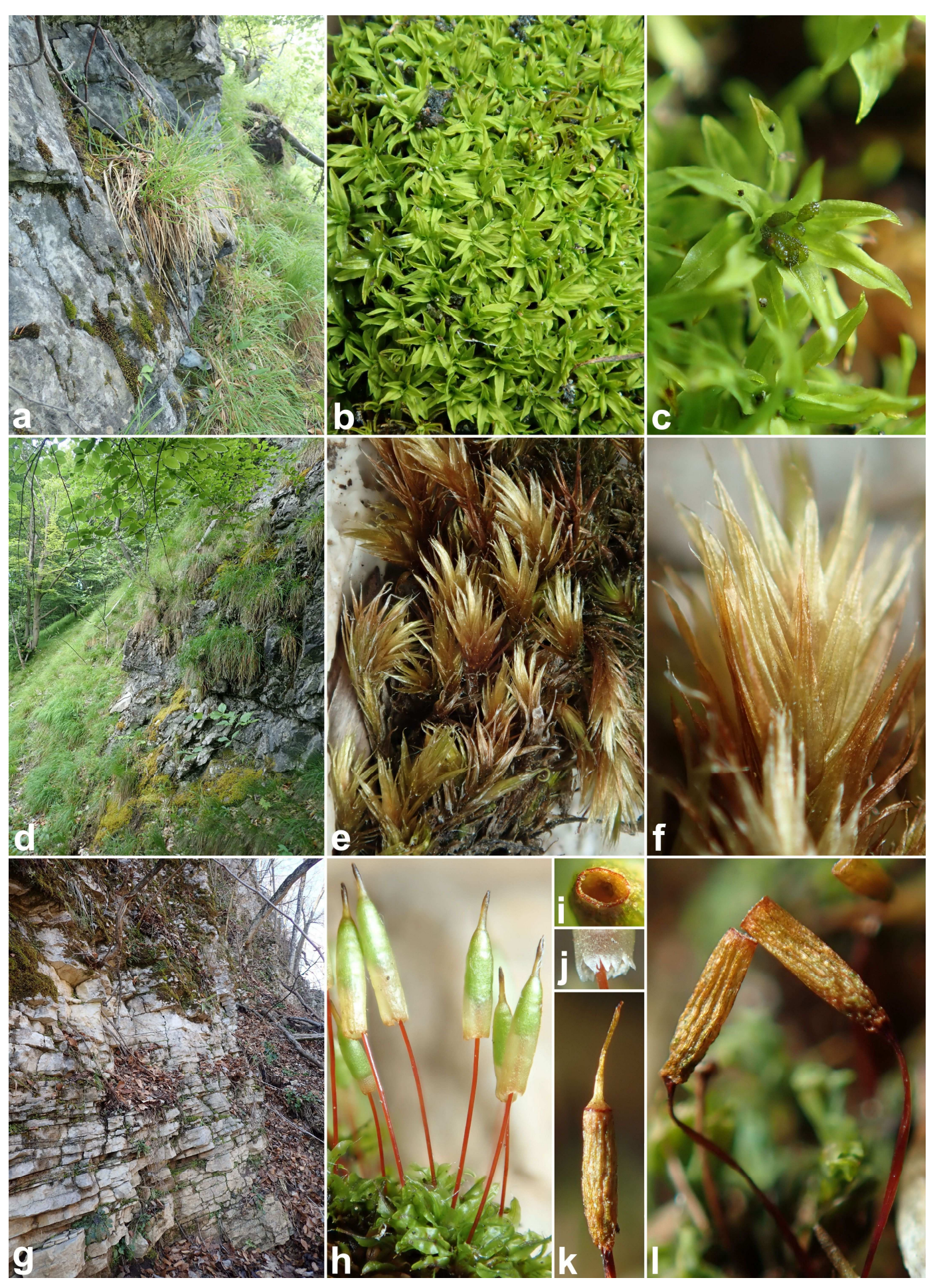


2. ábra (az előző oldalon) a-c: Hydrogonium croceum. a: Élőhely (Ómassa, Jávor-hegy, 2021.07.06), b-c: Habitus a jellegzetes levélhónalji gemmákkal. d-f: Orthothecium rufescens. d: Élőhely (Ómassa, Jávor-hegy, 2021.07.06), e-f: Habitus a jellegzetesen hosszredős, vöröses színú levelekkel. g-k: Encalypta spathulata. g: Élőhely (Ómassa, Vörös-kő, 2021.03.03), h: Habitus, i: spóratok szája, j: kaliptra alja, k-l: érett spóratokok. (Fotó: Németh Cs.)

Fig. 2 (previous page) a-c: Hydrogonium croceum. a: Habitat (Ómassa, Jávor Hill, 06. 07. 2021), b-c: Habit showing the characteristic axillary gemmae. d-f: Orthothecium rufescens. d: Habitat (Ómassa, Jávor Hill, 06. 07. 2021), e-f: Habit showing the characteristic plicate, reddish leaves. g-k: Encalypta spathulata. g: Habitat (Ómassa, Vörös-kő Hill, 03. 03. 2021), h: Habit, i: mouth of capsule, j: base of calyptra, k-l: mature capsules. (Photos by Cs. Németh)

\section{Encalypta spathulata Müll.Hal.}

Mészkő- és dolomitsziklákon élő, montán, boreális-szubalpin faj. A környező országok közül Ausztriából, Szlovákiából, Romániából és Szerbiából ismert, mindenütt ritka, veszélyeztetett faj (HoDGETTS \& LOCKHART 2020). Magyarországi élőhelye a Bükkben, a Miskolc-Ómassa feletti Vörös-kőn található (KEF: 7889.3; N 4806'53.9"', E 20³1'36.4", ca. 565 m, 2021. 03. 03., 2021. 05. 06., 2021. 07. 06. leg. Németh Cs. és Schmotzer A., det. Németh Cs., conf. P. Erzberger (hb. Cs. Németh 10460, 10555, 10694, BP 197265) (1, 2g ábra).

Világoszöld vagy olívzöld, sűrű gyepekben növő, kistermetű $(0,8-1 \mathrm{~cm})$ faj. Keskeny nyelv- vagy nyújtott tojásdad alakú, sima szélű, jellemzően tompa csúcsú levelei (3d ábra) szárazon csavarodottak, nedvesen elállók. A hajtások felső levelei a csúcsukon hosszú, gyengén fogazott, törékeny hialinszőrt viselnek (2h, 3e ábra). A levélér erőteljes, sárgás színű, a levélalapban vöröslő, az idősebb leveleknél teljes hosszában vörösesbarna. A felső és középső levélsejtek négyzet vagy hatszög alakúak, sűrűn papillásak, átlátszatlanok. A levélalap sejtjei téglalap alakúak, sárgák, simák, vastag falúak, a levél szélén 2-3 sor keskeny, hosszúkás sejtekből álló szegéllyel határoltak. Egylaki, spóratokot gyakran fejleszt, a toknyél sima, vörös színű. Toksüvege fényes, áttetsző, finoman papillás, az alja markánsan karéjos-rojtos (2j ábra). A spóratok henger alakú, 8-16 hosszanti csíkkal, amik a tok kiszáradását követően többé-kevésbé erőteljes bordákat formálnak (2k-l ábra). Perisztómium fogak nincsenek, a tokszáj peremén mindössze egy 1-2 vöröses sejtből álló karima figyelhető meg (2i, $3 \mathrm{~g}$ ábra). A tokfedő hosszú csőrös (2k ábra). Spórái sápadt sárgásak vagy barnásak, szemölcsösek, a vörös-kői példány spóramérete 32-36 (-38) ㅆm (3f ábra).

Leginkább hasonló faj a Magyarországon korábban szintén a Bükk területén gyüjtött Encalypta rhaptocarpa Schwaegr. (ERZBERGER 2014), melynek felső levelei szintén hialinszőrben végződnek, de tokja erőteljesebben bordázott, jól fejlett perisztómium fogai vannak, kaliptrájának alapi része szinte teljesen ép, vagy csak alig hasadozott, spórái jellemzően valamivel nagyobbak. Az E. spathulata a többi hazánkban előforduló Encalypta fajtól is könnyen elkülöníthető. A kétlaki, sporofitont csak ritkán fejlesztő és leginkább barna, fonalszerű, levélhónalji gemmákkal szaporodó Encalypta streptocarpa Hedw. levelei nem hialinszőrösek, hosszú perisztómium fogakat hordozó tokja pedig spirálisan bordás. A szintén perisztómium nélküli $E$. vulgaris Hedw. levele tompa csúcsú, a levélér jellemzően a levélcsúcs alatt végződik (ritkán kissé kilépő), tokja sima, vagy csak alig bordázott, a kaliptra alapja ép, vagy csak alig erodált. A szintén rojtos toksüvegú $E$. ciliata Hedw. toknyele sárga, jól fejlett perisztómium fogakkal rendelkező tokja sima falú, leveleinek csúcsán kis szálkahegy, nem pedig hosszú hialinszőr található (NyHOLm 1998, GuERRA et al. 2006, CASAS et al. 2006, MAGILl 2007, FEDOSOV 2012, KÖCKINGER et al. 2021). 


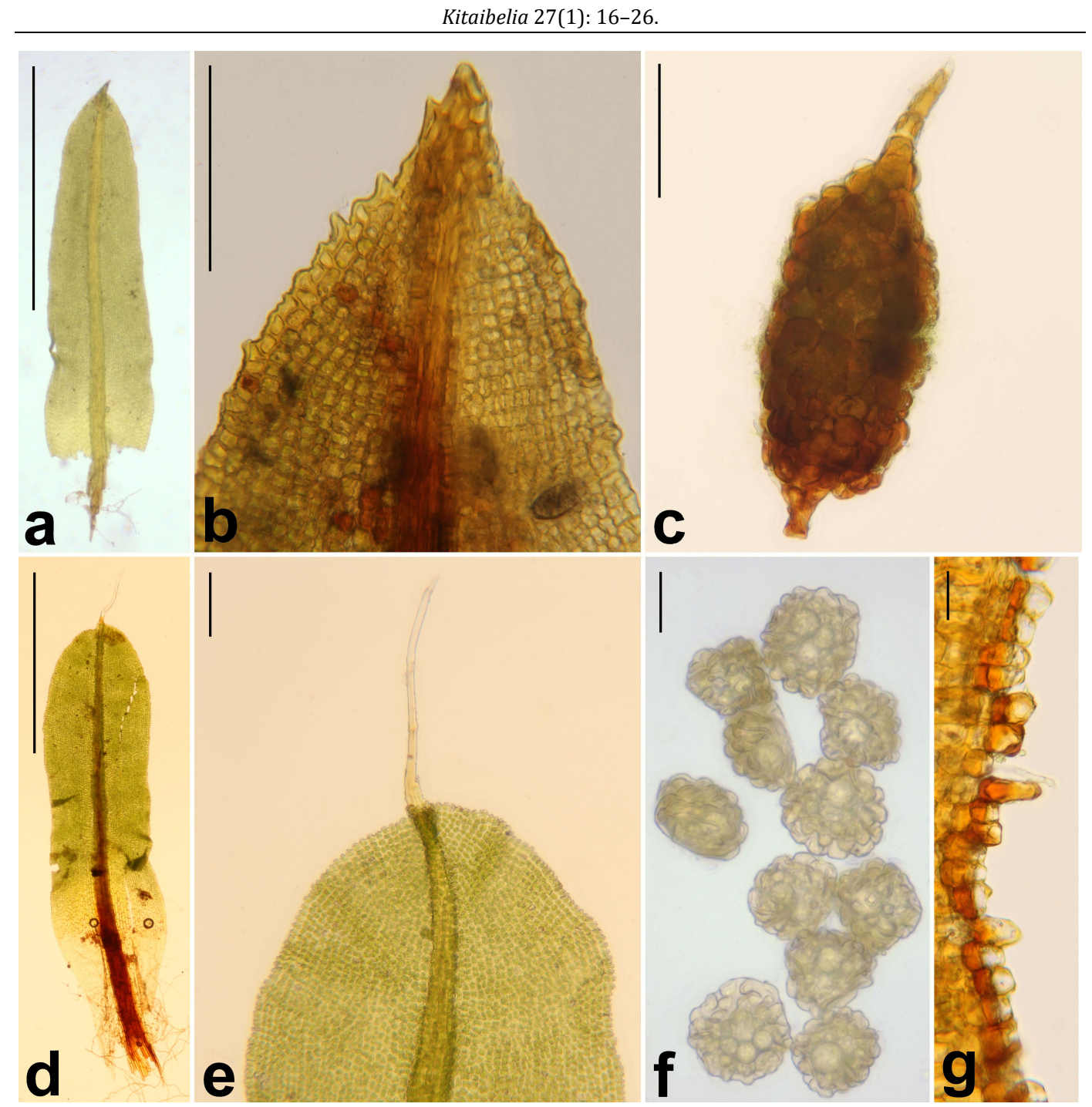

3. ábra a-c: Hydrogonium croceum. a: levél, b: levélcsúcs, c: gemma. d-g: Encalypta spathulata. d: levél, e: levélcsúcs, f: spórák, g: spóratok szája.

Méretvonal: a, $\mathrm{d}=1 \mathrm{~mm}, \mathrm{~b}-\mathrm{c}, \mathrm{e}=100 \mu \mathrm{m}, \mathrm{f}-\mathrm{g}=20 \mu \mathrm{m}$. (Fotó: Cs. Németh)

Fig. 3 a-c: Hydrogonium croceum. a: leaf, b: leaf apex, c: gemma. d-g: Encalypta spathulata. $\mathrm{d}$ : leaf, e: leaf apex, f: spores, g: mouth of capsule. Scale bars: $a, d=1 \mathrm{~mm}, \mathrm{~b}-\mathrm{c}, \mathrm{e}=100 \mu \mathrm{m}, \mathrm{f}-\mathrm{g}=20 \mu \mathrm{m}$. (Photos by Cs. Németh)

\section{Értékelés}

Földrajzi adottságaiból adódóan Magyarország nem bővelkedik magashegyi karakterű mohafajokban. Az a néhány montán, dealpin-boreális flóraelem (pl. Metzgeria pubescens (Schrank) Raddi, Mannia triandra (Scop.) Grolle, Myurella julacea (Schwägr.) Schimp., Orthothecium intricatum (Hartm.) Schimp., Ptychostomum zieri (Hedw.) Holyoak et N. Pedersen, Plagiopus oederianus (Sw.) H. A. Crum et L. E. Anderson, stb.) szinte kizárólag a Magyar-középhegység dolomit vagy mészkő alkotta területein, északias kitettségű sziklák, meredek, sziklás lejtők, 
sziklagyepek, sziklaerdők kínálta mikroklimatikus zugokban, sokszor glaciális reliktumként tekintett virágos növények (pl. Allium victorialis L., Carduus crassifolius Willd. subsp. glaucus (Baumg.) Kazmi, Primula auricula L.) társaságában fordul elő (Boros \& VAjDA 1963, BoRos 1968, NÉMETH 2007, 2008, NÉMETH \& PAPP 2011). A bükki Nagy- és Kis-fennsík közé beékelődő Garadna-völgy környéke különösen gazdag ilyen típusú, reliktumőrző élőhelyekben. Ezek egyike az Ómassa feletti Jávor-hegy Garadna-völgyre tekintő sziklás letörése. A hegy meredek, északi kitettségű lejtőjén, dolomit alapkőzeten (Hámori Dolomit Formáció) kifejlődött növénytársulások (Calamagrostio variae-Seslerietum variae Vojtkó 1998, Seslerio hungaricaeFagetum Zólyomi 1967) számos hazánkban ritka, magashegyi karakterrel rendelkező edényes növényfaj élőhelyei (pl. Calamagrostis varia (Schrad.) Host, Sesleria caerulea (L.) Ard., Rubus saxatilis L., Asplenium viride Huds., Valeriana tripteris subsp. austriaca E. Walther.). A Hydrogonium croceum és az Orthothecium rufescens ilyen környezetben, a hegyoldal dolomit sziklafalainak repedéseiben él más, részben szintén montán, dealpin mohafajokkal társulva (Ctenidium molluscum (Hedw.) Mitt., Distichium capillaceum (Hedw.) Bruch \& Schimp., Fissidens dubius P.Beauv., Mannia triandra (Scop.) Grolle, Mesoptychia collaris (Nees) L. Söderstr. \& Váňa).

Az ómassai Vöröskő, mint földrajzi hely szélesebb értelmű interpretációja magában foglalja a közvetlenül a település felett magasodó triász dolomitból (Hámori Dolomit Formáció) felépülő Gula-hegyet, valamint az attól északra magasodó tulajdonképpeni Vörös-kő triász mészkőtömbjét (Gerennavári Mészkő Formáció). A két rögöt egymástól a Száraz-völgy mély szurdoka választja el. A Gula-hegy északi kitettségű szikláin a Jávor-hegyhez hasonló, szubalpin elemekben gazdag mohaflórát találunk (Distichium capillaceum (Hedw.) Bruch \& Schimp., Mesoptychia collaris (Nees) L. Söderstr. \& Váňa, Orthothecium intricatum (Hartm.) Schimp., Pedinophyllum interruptum (Nees) Kaal., Plagiopus oederianus (Sw.) H. A. Crum et L. E. Anderson, Scapania aequiloba (Schwägr.) Dumort., Scapania aspera M. Bernet et Bernet). A Mannia triandra itteni előfordulásáról „Vöröskő" lelőhely megnevezéssel tudósító publikáció is dolomit alapkőzetet említ, és a közölt edényes fajlista (Clematis alpina (L.) Mill., Calamagrostis varia (Schrad.) Host, Cirsium erisithales (Jacq.) Scop., SILLER 1979) is inkább a Gulahegyre utal. A Vörös-kő kissé szárazabb mészkőszikláiról a fenti mohafajok zöme hiányzik, vagy jóval kisebb borításban van jelen. A mészkősziklák alatti meredek, kőtörmelékes lejtő magaskőrises-juharos sziklaerdeje (Scolopendrio-Fraxinetum Schwickerath 1938) pedig meglehetősen nitrofil aljnövényzetű, benne sok Sambucus nigra L., Aegopodium podagraria L., Chelidonium majus L., Geranium robertianum L., Urtica dioica L., szemben a Gula bükkös sziklaerdejével, ahol a SILLER Irén (1979) által jelzett edényes fajok nagy tömegben előfordulnak, egyéb figyelemre méltó fajok (Asplenium viride Huds., Daphne mezereum L., Gymnocarpium robertianum (Hoffm.) Newman, Orthilia secunda (L.) House, Viola collina Besser) társaságában.

Az E. spathulata a Vörös-kő északkeleti kitettségű, Farkasnyaki-völgyre néző függőleges mészkő sziklafalának párkányain, valamint a sziklafal alatt egy kidőlt fa gyökértányérján, sziklatörmelékes talajon él, javarészt közönséges, gyakori mohafajokkal társulva (Alleniella besseri (Lobarz.) S. Olsson, Enroth \& D. Quandt, Brachytheciastrum velutinum (Hedw.) Ignatov \& Huttunen, Brachythecium tommasinii (Sendtn. ex Boulay) Ignatov \& Huttunen, Encalypta streptocarpa Hedw., Fissidens dubius P. Beauv., Homalothecium sericeum (Hedw.) Schimp., Ptychostomum capillare (Hedw.) Holyoak \& N. Pedersen, P. elegans (Nees.) D. Bell \& Holyoak, P. moravicum (Podp.) Ros \& Mazimpaka, Streblotrichum convolutum (Hedw.) P. Beauv. var. commutatum (Jur.) J. J. Amann, Tortella tortuosa (Hedw.) Limpr.).

Mind a Jávor-hegy, mind pedig az ómassai Vöröskő edényes flóráját és vegetációját számos botanikus tanulmányozta (SUBA et al. 1982, BAKALÁR et al. 1983, TöRÖK \& ZóLYOMI 1998, VojTKó 1994, 1995, 1999, 2001, SULYOK et al. 2015). Terepi naplóinak bejegyzései alapján Boros Ádám is többször megfordult az Ómassa környéki területeken (BoRos 1915-1971), de 
valószínűleg a Jávor-hegy szikláihoz nem jutott el, hiszen elég valószínűtlen, hogy a $H$. croceum és az 0 . rufescens, ez a két szembetűnő, karakterisztikus megjelenésű faj elkerülték volna a figyelmét. Figyelembe véve, hogy a Központi-Bükk mohaflorisztikailag kiemelkedően jól feltárt terület, továbbá, hogy a Jávor-hegy északi, meredek letörése hazai viszonylatban sok szempontból unikálisnak, bükki viszonylatban pedig az egyik, ha nem a legmontánabb élőhelynek tekinthető, utóbbi két erőteljesen montán karakterű, mészkedvelő mohafaj további hegységbeli és egyéb hazai előfordulása kevéssé várható. Európai léptékben, adekvát termőhelyeken mind a $H$. croceum, mind pedig az $O$. rufescens elterjedtnek mondható. Az európai viszonylatban meglehetősen ritka E. spathulata vörös-kői élőhelye ezzel szemben sem edényes, sem moha fajkészletében nem mutat különösebb specialitásokat. Ez alapján a faj a jövőben akár a hegység más, hasonló élőhelyi adottságokkal rendelkező területeiről is előkerülhet.

\section{A fajok veszélyeztetettségi státuszának értékelése}

A H. croceum és az O. rufescens az IUCN vörös listáján nem fenyegetett (Least Concern; LC), míg az E. spathulata sebezhető (Vulnerable; VU) besorolással szerepel (HODGETTS et al. 2019).

Az IUCN kritériumrendszere alapján (IUCN Standards and Petitions Subcommittee 2017) - mivel az előfordulások kiterjedése kisebb, mint 100 km² (B1 kategória); a populációk által elfoglalt terület nagysága kisebb, mint $10 \mathrm{~km}^{2}$ (B2 kategória); az ismert lokalitások száma 1 (B2a kategória), és a kis állományméret miatt a szubpopulációk számbeli csökkenésének lehetősége is fennáll (B2b kategória); továbbá a hazai teljes populáció becsült egyedszáma kevesebb, mint 250 (C kategória), illetve 50 (D kategória); valamint a szubpopulációk egyedszáma is kisebb, mint 50 (C2a kategória) - mindhárom faj a felsorolt valamennyi kritériumpont alapján CR kategóriába esik, így a magyarországi vörös listás értékelésüket kipusztulással veszélyeztetettként (CR) javasoljuk. A múltbéli és jövőbeni populációméret-csökkenés (A és C1 kategória), valamint a lehetséges jövőbeni eltűnés valószínűségének megítéléséhez (E kategória) nem rendelkezünk kellő információval, illetve a populációkra vonatkozó visszamenőleges kvantitatív adatokkal.

\section{Köszönetnyilvánítás}

Köszönet illeti Sulyok Józsefet terepi tapasztalatainak megosztásáért, illetve Peter Erzbergert a határozások helyességének megerősítéséért. Köszönjük továbbá a bírálók hasznos észrevételeit és építő javaslatait.

\section{Irodalom}

BAKALÁR S., ORBÁN S., SUBA J. \& TAKÁCS B. (1983): A Cypripedium calceolus L. feltárt termőhelyei a Bükkhegységben és környékén. - Folia Historico-Naturalia Musei Matraensis 8: 77-83.

BiRKS H.J.B. \& HodgetTS N.G. (2014): Orthothecium rufescens (Dicks. ex Brid.) Schimp. - In: BlockeEL T.L., BosAnQuet S.D.S., HILl M.O. \& PRESTON C.D. (eds.) (2014), Atlas of British and Irish Bryophytes. Volume 2, $570 \mathrm{pp}$.

BoRHIDI A. (2003): Magyarország növénytársulásai. - Akadémiai Kiadó, Budapest, 610 pp.

Boros Á. (1915-1971): Florisztikai jegyzetek. - MTM, Tudománytörténeti Gyűjtemény, Budapest, mscr.

Boros Á. (1968): Bryogeographie und Bryoflora Ungarns. - Akadémiai Kiadó, Budapest, 466 pp.

Boros Á. \& VAjDA L. (1963): A Bakony dolomitjának mohaföldrajza. - A Veszprém Megyei Múzeumok Közleményei 1: 281-286. 
CASAS C., Brugues M., Cros R.M. \& SERgio C. (2006): Handbook of Mosses of the Iberian Peninsula and the Balearic Islands: Illustrated keys to genera and species. - Institut d'Estudis Catalans, Barcelona, 349 pp.

CASPARI S. \& ERZBERGER P. (2019): Tortella pseudofragilis (Thér.) Köckinger \& Hedenäs. - In: ElLIS L.T. (ed.), New national and regional bryophyte records, 58. - Journal of Bryology 41(1): 63-84.

ERzBerger P. (2009): The genera Grimmia and Coscinodon (Grimmiaceae, Musci) in Hungary. - Studia Botanica Hungarica 40: 37-124.

ERzBerger P. (2014): Encalypta rhaptocarpa Schwaegr. - In: Elbis L.T. (ed.), New national and regional bryophyte records, 39. - Journal of Bryology 36: 134-151.

ERzBerger P. \& SchröDer W. (2008): The genus Schistidium (Grimmiaceae, Musci) in Hungary. - Studia Botanica Hungarica 39: 27-88.

Erzberger P., Németh Cs., PapP B., Mesterházy A., Csiky J. \& Baráth K. (2015): Revision of the red list status of Hungarian bryophytes 1 . New occurrences of species previously thought to be regionally extinct or without recent data. - Studia Botanica Hungarica 46(2): 15-53.

ERzBerger P. \& PAPP B. (2020): The checklist of Hungarian bryophytes. - second update. - Studia Botanica Hungarica 51(2): 11-76.

FEDosov V. E. (2012): Encalypta sect. Rhabdotheca in Russia. - Arctoa 21: 101-112.

Galambos I. (1992): A Barbula s.l. nemzetség magyarországi fajainak revíziója. - Folia Musei HistoricoNaturalis Bakonyiensis 11: 37-144.

Guerra J., Cano M.J. \& Ros R.M. (eds.) (2006): Flora Briofítica Ibérica. Vol. III. Pottiales, Encalyptales. UMU/SEB, Murcia, 305 pp.

Herben T., KuRKovÁ J., SOldán Z. \& VÁŇA J. (1982): Př́spěvek k rozšíření mechorostů v oblasti Slovenského raje. - Zprávy České botanické společnosti 17: 105-119.

HERBEN T. \& SOLDÁN Z. (1987): Bryofloristic material from the central part of Muranska planina (Western Carpathians). - Preslia 59: 65-85.

Hodgetts N., CÁlix M., Englefield E., Fettes N., García Criado M., ... \& Żarnowiec J. (2019): A miniature world in decline: European Red List of Mosses, Liverworts and Hornworts. - Brussels, Belgium: IUCN.

HODGETTS N. \& LOCKHART N. (2020): Checklist and country status of European bryophytes - update 2020. Irish Wildlife Manuals, No. 123. National Parks and Wildlife Service, Department of Culture, Heritage and the Gaeltacht, Ireland

IUCN Standards and Petitions Subcommittee (2017): Guidelines for using the IUCN Red List Categories and Criteria. Version 14. - Prepared by the Standards and Petitions Subcommittee, 113 pp. http://cmsdocs.s3.amazonaws.com/RedListGuidelines.pdf

KIRÁLY G. (2003): A magyarországi flóratérképezés módszertani alapjai. Útmutató és magyarázat hálótérképezési adatlapok használatához. - Flora Pannonica 1: 3-20.

KIRÁLY G. (szerk.) (2009): Új magyar füvészkönyv. Magyarország hajtásos növényei. Határozókulcsok. ANP Igazgatóság, Jósvafő, 616 pp.

Kovács P. (2017): A Bükk csapadékviszonyai. - Múszaki Földtudományi Közlemények 86(3): 43-57.

KöCKINGER H., KuČERA J., HOFMANN H., MüLLER N. \& AMANN G. (2012): Barbula consanguinea discovered in Switzerland and Austria, with a revision of former European records of B. indica. - Herzogia 25: 6170.

KöCKInger H., Berney I. \& Hofmann H. (2021): Encalypta spathulata Müll.Hal. - In: Swissbryophytes Working Group (Hrsg.), Moosflora der Schweiz, www.swissbryophytes.ch, compiled 25/08/2021

MAGiLl R.E. (2007): Encalyptaceae Schimper. - In: Flora of North America Editorial Committee (ed.), Flora of North America: North of Mexico. Vol. 27. Oxford University Press, New York, pp. 170-179.

Nebel M. \& PhilipPI G. (eds.) (2000): Die Moose Baden-Württembergs, I. (Andreaeales bis Funariales). Ulmer, Stuttgart, $512 \mathrm{pp}$.

NÉMETH Cs. (2007): Data on the distribution of some rare alpine-boreal bryophytes in the Vértes Mts. (Hungary). - Studia Botanica Hungarica 38: 59-70.

NÉMETH Cs. (2008): Adatok a Súri-Bakonyalja, a Bakony és a Vértes mohaflórájához. - Flora Pannonica 6: 79-87.

NÉmEth Cs. \& PAPP B. (2011): Mannia triandra in the Transdanubian Mountain Range (Hungary). Studia Botanica Hungarica 42: 23-29.

NÉMETH Cs. \& SchmotZer A. (2021a): Hydrogonium croceum (Brid.) Jan Kučera, Orthothecium rufescens (Brid.) Schimp. [Hungary]. In: ElLIS L.T. (ed.), New national and regional bryophyte records, 67. Journal of Bryology 43(3): 301-311. 
NÉmeth Cs. \& Schmotzer A. (2021b): Encalypta spathulata Müll. Hal. [Hungary]. In: ElLIS L.T. (ed.), New national and regional bryophyte records, 68. - Journal of Bryology 43(4): 387-402.

Nyноцм E. (1998): Illustrated Flora of Nordic Mosses. Fasc. 4. Aulacomniaceae-MeesiaceaeCatoscopiaceae-Bartramiaceae-Timmiaceae-Encalyptaceae-Grimmiaceae-PtychomitraceaeHedwigiaceae-Orthotrichaceae. - Nordic Bryological Society, Copenhagen, pp. 249-405.

ORBÁN S. (1980): Adatok a Bükki Nemzeti Park (BNP) mohaflórájának ismeretéhez. - Folia HistoricoNaturalia Musei Matraensis 6: 71-72.

ORBÁN S., PÉnZESNÉ KóNYA E. \& SASS-GYARMATI A. (2009): Radiolarit és agyagpala alapkőzeten kialakult acirofil erdőtársulások kriptogám vegetációjának leírása a Bükk hegységből. - Acta Academiae Paedagogicae Agriensis 36: 3-20.

PAPP B. (2008): Selection of Important Bryophyte Areas in Hungary. - Folia Cryptogamica Estonica 44: 101-111.

PAPP B. \& ERZBERGER P. (2003): Data about the actual local populations of bryophyte species protected in Hungary. - Studia Botanica Hungarica 34: 33-42.

PELIKÁN P. (szerk.) (2005): A Bükk hegység földtana. Magyarázó a Bükk hegység földtani térképéhez (1:50000). - Magyarország tájegységi térképsorozata. Budapest. Magyar Állami Földtani Intézet, $251 \mathrm{pp}$.

PÉNZESNÉ KóNYA E. \& ORBÁN S. (2000): A Bükk hegység radiolarit alapkőzetű területeinek mohaflórája II. - Kitaibelia 5(1): 125-130.

Šıí́к J., Petrík A. \& KLiment J. (2004): Syntaxonomical revision of plant communities with Carex firma and Dryas octopetala (alliance Caricion firmae) in the Western Carpathians. - Polish Botanical Journal 49(2): 181-202.

SilLER I. (1979): Mannia triandra (Scop.) Grolle in Hungary. - Acta Botanica Academiae Scientiarum Hungaricae 25: 139-142.

Sмiтн A.J.E. (2004): The Moss Flora of Britain and Ireland, 2nd ed. - University Press, Cambridge, 1012 pp.

SUBA J., TAKÁCS B. \& LÉGRÁDY G. (1982): A Jávor-hegy Ómassa fölötti északi oldalának botanikai értékei. Abstracta Botanica 7: 45-48.

SulyoK J., VojtKó A. \& Somlyay L. (2015): A Viola collina Besser előfordulása a Bükkben és az Upponyihegységben. - Kitaibelia 20(2): 254-258.

SzABó J. (1981): Adatok a Garadna-forrás vízgyűjtő területének vizsgálatához. - Karszt és Barlang 1981(1-2): 9-12.

SzÚcs P., József J., PAPP V.G. \& KuTSZEgi G. (2015): A veszélyeztetett Anacamptodon splachnoides (Froel. ex Brid.) Brid. új adata a Bükk-hegységből. - Kitaibelia 20(2): 202-205.

Tóтн Z. (1987): A phytogeographic review of Tortula Hedw. Sect. Rurales De Not. (Pottiaceae, Musci) in Hungary. - Acta Botanica Hungarica 33: 249-278.

TöRöK K. \& ZóLYOMI B. (1998): A Kárpát-medence öt sziklagyeptársulásának szüntaxonómiai revíziója. In: Csontos P. (szerk.), Sziklagyepek szünbotanikai kutatása. Scientia Kiadó, Budapest, pp. 109-132.

VojTKó A. (1994): Adatok a Bükk hegység flórájához. - Botanikai Közlemények 81: 165-175.

Vојтко́ A. (1995): Asplenium lepidum C. Presl in Hungary. - Acta Botanica Hungarica 39(3-4): 243-248.

VojTKó A. (1999): A Valeriana simplicifolia (Reichenb.) Kabath hazánkban és újabb adatok a Bükk hegység flórájához. - Kitaibelia 4(1): 25-35.

VojTKó A. (szerk.) (2001): A Bükk hegység flórája. - Sorbus Kiadó, Eger, 340 pp.

ZANDER R.H. (1994): Pottiaceae. - In: Sharp A.J., CRum H.A. \& Eckel P.M. (eds.), The moss flora of Mexico. Memoirs of the New York Botanical Garden 69: 211-386.

Beérkezett / received: 2021. 11 .29. • Elfogadva / accepted: 2022. 01. 09. 